\title{
Doubling of Farmers Income through Animal Husbandry by 2022
}

\author{
Deepika Tekam $^{1}$, Nikita Sonawane ${ }^{1}$, Adhiti Bhanotra ${ }^{2}$ and Manish Sawant ${ }^{2 *}$ \\ ${ }^{1}$ Department of Veterinary and Animal Husbandry Extension, Mumbai Veterinary College, \\ Parel-400 012, India \\ ${ }^{2}$ Maharashtra Animal and Fishery Sciences University, Nagpur, India \\ *Corresponding author
}

\section{Keywords}

Doubling, Farmers Income, Animal husbandry,

Livestock

management

Article Info

Accepted:

22 January 2019

Available Online:

10 February 2019

\section{A B S T R A C T}

In India livestock sector play important role to improve the economic condition of farmers. About $70 \%$ of livestock population is control by the landless, small and marginal farmers which are the source of income for farmers. Concept of doubling of farmer's income by 2022 was given by Hon Prime Minister Mr. Narendra Modi ji on February 29, 2016 in Bareilly Uttar Pradesh. Department of Animal Husbandry, Dairying and Fisheries formulated various schemes regarding increase in milk production; improvement in the quality of indigenous breed of animal, increase the availability of feed and fodder. Various schemes are implemented in central and state level such as; Dairy Entrepreneurship Development programme, Livestock health and disease control scheme, Feed and Fodder Development scheme, Rashtriya Gokul Mission etc. through which income of framers can be doubled. Policy support services such as Kisan credit card, women SHGs, farmer's federation, NGOs also provide financial support to the farmers. Animal husbandry department also play important role in providing information to the farmers by organizing camp in village regarding vaccination of economic diseases like FMD, PPR, HS and also guide farmers about livestock management practices, knowledge regarding value addition and benefit of diversification in animal husbandry.

\section{Introduction}

In India about $70 \%$ farmer's livelihood depends on agriculture sector. Agriculture sector plays an important role in Indian economy. In India income of farmers varies from state to state. According to (NSSO 2012-13) monthly income of farmers was 6,426 Rs (Kumari, 2017). Average monthly income per capita of farmers was 3,844 Rs (Dinani, 2017). That Income is not sufficient to fulfill their daily basis need in $21^{\text {st }}$ century.
So here it is important to focus on double the farmer's income.

After the Green Revolution, India's food production multiplied by 3.7 times while the population multiplied by 2.55 times (Chand, 2017).

In India food production has increased from 51 million tonnes to 273 million tonnes in 1950-51 to 2016-17 (Chand, 2017).

Net result has been a $45 \%$ increase in per person food production, which has made India 
not only food self sufficient at aggregate level but also a net food exporting country (Chand, 2017).

Doubling of farmer's income by 2022 given by Hon. Prime Minister Narendra Modiji \& was announced by Hon. Finance Minister Arun Jaitley during his budget speech on February 29, 2016 in Bareilly (U.P),(Chand, 2017).

\section{Need to double the farmer's income:-}

\section{Promote farmers welfare}

Adoption of new technologies which helps to increase in the productions and growth of farmers (Chand, 2017). Various schemes and Yojnasare also developed by Department of Animal Husbandry, Dairying \& Fisheries or the promoting of farmers welfare. E.g.-: ENAM (Electronic: -National agriculture market) (Kumar, 2018) Pradhan Mantri Fasal BimaYojna (PMFBY), Dairy Entrepreneurship Development program, National Livestock Mission etc. (DAHDF 2017).

\section{Agrarian distress}

India is the world's $2^{\text {nd }}$ largest agriculture producer. Farming can be very risky business due to; unpredictability of weather, crop and market. That unpredictability for small farmers led many into agrarian distress (Chand, 2017).

\section{Increase number of farmer's suicides}

Famers suicide a very complex phenomenon largely associated with economic, social and psychological distress. There are several causes of farmer's suicides which include: Increase cost of production, globalization and exploitation from money lending sources, shrinking water table, repeated crop failure, natural calamities and lack of alternative source of income bring down the farmers suicides (Chand, 2017).

\section{Rural youth less interested in farming}

Lack of credit and negative perception towards farming; leading young people less interested and leave farming (Chand, 2017). Youth are not continuing as farmers due to, falling profitability and income in agriculture. Attracting and Retaining Youth in Agriculture (ARYA) \& Rural Entrepreneurship Awareness Development Yojna (READY) are the two schemes developed by Government of India for the educating of rural youth toward farming(Indian ministry of Agriculture and farmers welfare 2018).

\section{Concept}

Influencing farming ability: Introducing modern technology like hybrid seed, variety of crop, advance equipments, water irrigation techniques, fertilizers, pesticides, milking methods and skill development programmes also influence the ability of farmers.

Improve economic condition: Diversification is a key strategy in improving the economic condition of farmers by creating a source of income as dairy farming, poultry farming, livestock farming etc. Provide information to the farmers regarding restore soil health and fertility, seed quality, promoting agriculture and livestock business in rural area. Implementations of livestock policy measure and livestock development programmes help to improve the economics condition of farmers (Chand, 2017).

Eradicating poverty: In India about 21.90 per cent populations live in below poverty line. Poverty in India is concentrated farming communities; farm women, men, children dependent on a precarious balance of multiple livelihoods in which hunger is a daily fact of life where access to basic services like education, health and water supply is difficult. 
Enhance livelihood: Small holder farmers have less than 2 hectares land and depend on labour supply by household members and few other inputs. Through diversification, integrated farming and contract farming help to enhance access to finance and input resources (Chand, 2017).

\section{Source of growth in farmer's income}

\section{Increase the productivity of animals}

Through widening the coverage of A.I: In India coverage under A.I in cattle and buffalo hardly $35 \%$. The main reason for low A.I is less supply of semen straw. We requires 160 million doses of semen straws against the availability of 81 millions to reach the reasonable A.I number (Niti policy Paper, 2017).

Improving the productivity efficiency of dairy animal: Improvement in feeding and housing management, health management; prevention from reproductive diseases such as anestrous, delayed puberty, delayed heat. Improve in genetic material and various breeding method help to enhance the productivity of dairy animal (Niti policy Paper, 2017).

Technology generation and dissemination: In livestock, information technology used for dissemination of livestock related information such as; vaccination alert can be delivered through mobile service before Monsoon (Dinani, 2017).

\section{Diversification}

Livestock play an important role in the welfare of Indian farmers. Crop-livestock diversification is the best livelihood strategies for farm household. This system provides increased stability in income, food security; transport fuel and nutrition to the farmer's.
Livestock sector alone provide alternative livelihood option to over 70 millions small and marginal farmers. Meat, egg, wool and their by products are also emerging as important productive sector for diversification (Dinani, 2017).

\section{Value addition}

Value addition is a process of changing and transforming a product from its original state to a more valuable state. Product development is a way that enhances the value of milk and meat by products. Local farmers also get the benefit if they engage in value addition activities which enhance the value of livestock(Dinani, 2017).

\section{Role of livestock sector}

Livestock sector is important subsector of the agriculture of the Indian economy. Animal husbandry provide livelihood support to $2 / 3$ of rural household specially the landless and marginal farmers who control $70-75 \%$ of livestock population its forms an important livelihood activity for most of the farmers supporting agriculture in the form of critical input, contributing to health and nutrition of the household supplementary income, offering employment opportunities and finally being dependable "bank on hooves" in times of need. It acts as supplementary and complimentary enterprise (Dinani, 2017). Contribution of Gross Domestic Product (GDP) $25.6 \%$ of agriculture GDP and $4.11 \%$ National GDP from livestock sector (2012). As per $19^{\text {th }}$ livestock census (2012):-

\section{Dairy development}

(DAHD, Annual Report 2017-18): -Dairy development as an important source of additional income for the farmer's. Availability of milk processing facility and other infrastructure will benefit the farmers 
through value addition.

India's rank $1^{\text {st }}$ among the world's milk producing Nation.

Milk production in India, 176.4 million tonnes.

Growth rate of milk production $6.65 \%$.

Per capita availability of milk in country 374 grams per day in 2017-2018.

\section{Various schemes for Dairy Development}

National dairy development programme: Focus on creating /strengthening of infrastructure for production of quality milk, procurement, processing and marketing of milk and milk by product.

Dairy entrepreneurship development scheme: Objective of that scheme to generate self employment in dairy sector in the country. This scheme is being implemented through NABARD which provide financial assistance.

National dairy plan phase1: Objective of scheme to increase productivity of milch animal and thereby increase milk production to meet the rapidly growing demand for milk through scientific breeding and feeding.NDP1 is a central scheme of GOI being implemented by National Dairy Development Board.

Target of milk production has been kept at 254 million tonnes by 2022 .

\section{Poultry Development (DAHD, Annual Report 2017-18)}

Poultry production in our country is 729.21 millions. Egg production is around 88 billion during 2016-17 (DAHD, Annual Report 2017-18). Per capita availability is around 69 eggs per annum 2016-17. Improve socioeconomic status of the farmers and provide nutritious food for people of society encourage poultry farming through various schemes. For example

Provide poultry rearing training with 2000/stipend is also to the farmers interested in poultry.

Provide poultry feed to farmers in reasonable rate and other technical facilities like vaccination, treatment debeaking, etc. these schemes are implemented by Intensive Poultry Development Block.

\section{Steps to double the farmer's income}

\section{Increase productivity of milch animal}

Milk production of individual animal (2-4 $\mathrm{kg}$ /day) in India is very low as compare to other countries. Various breeding programmes, breeding methods such as; inbreeding, out-breeding are used to Increase productivity of the individual animal through which farmer's income can be double(Kachhiapatel, 2018).

\section{Improvement of availability of fodder}

According to research India deficit in dry fodder by 10.00 per cent, in green fodder by 35.00 per cent and concentrate 33.00 per cent (Birthal and Jumrani, 2017). So availability of fodder improved by dietary manipulation, microbial manipulation and increases the production of fodder crop.

\section{Breeding policy}

Recent report of Government of India on grid statics of domestic species in the country shows that the pure breed of cattle, buffalo, sheep and goat are only $11.87 \%, 17.05 \%$, 38.86 and $26.97 \%$ respectively (Kachhiapatel, 2018). 


\section{Health and house management}

Sufficient Space requirement of individual animal, avoid over crowd of animals, proper ventilation, water management, feeding management, proper hygiene in animal shelter should be provide. Farmers should contribute for the Welfare and comfort of the animal and also have management of the animal (Kachhiapatel, 2018).

\section{Contract farming}

To provide for improve production and marketing of agriculture produce livestock and its product through holistic contract farming and to facilitate the contributing parties to develop mutually beneficial an efficient contract farming system by putting in place a friendly and effective institutional mechanism and conducts regulatory and policy Framework for contract farming (Kachhiapatel, 2018).

\section{Strategy for improvement of livestock production}

\section{Feeding management}

\section{Ration balancing}

Animal feed is most crucial input in livestock production feed shortage, poor nutritional quality of feed and imbalance feeding are the key problem on productivity. Feeding of balance ratio to dairy animal increase the productivity by reduce the feed cost, provide advisory service to the dairy farmers about optimal quantity of dry fodder, green fodder, concentrate supplements that should be fed to the dairy animal depending on age, breed, weight and stage of lactation. As per research with the help of ration balancing intervention enhance the productivity of cow by around $13.00 \%$ and buffalo by 5.50 per cent. Ration balancing intervention can double the farmers income with only 5.00 per cent increase in milk yield (price) and 5.00 per cent decline in feed cost (Lathwal, 2017).

\section{Increase forage availability}

Inter cropping and mix cropping are widely used to minimize the risk of failure, low water requiring and short duration forage such as; cow pea, cluster bean can be intercropped with long duration crop such as sorghum, pearl millet. Fodder production can be increased by raising fodder crop as catch crop between the main cropping seasons (Lathwal, 2017).

\section{Fodder bank}

Establishment of fodder banks in fodder scarcity region through dairy federation and organizations can help small farmers to feed their livestock during scarcity fodder bank can play an important role during drought (Lathwal, 2017).

\section{Improvement of nutritional value}

Major quantity of dry matter is contributed by paddy straw, wheat straw, maize stalk, sugarcane, bagasse which have poor nutritional value due to high fiber content. Urea treatment, water irrigation, heat treatment methods are used for improve the nutritional value of such fodder. This will also help in augmenting the fodder storage (Lathwal, 2017).

\section{Reduction of herd size}

It is necessary to create awareness among farmers to reduce herd size and ensure optimum feeding instead of maintaining a large number of underfed animals.

\section{Feeding of mineral mixture}

Animal should have free access to mineral 
brick and common salt so that deficiency of mineral like calcium phosphorus copper doesn't occur. Effective supplementation of mineral mixture on milk yield of animal, during lean period can be increased by balance concentrate having $2 \%$ of mineral mixture (Lathwal, 2017).

\section{Breeding services and general management}

Genetic improvement is $1^{\text {st }}$ step to produce superior quality bull, mother and calves.

Training and regulation of A.I technician: Skill oriented training for paravet to improve breeding efficiency. Periodic training regarding animal husbandry practice should be providing to the farmers.

Improve breeding practice: Application of super ovulation and embryo transfer technology for production of superior mother.

Shelter management: Improved animal shelter model with east west orientation was developed and promoted by CAZRI that created comfortable micro climate to animal during extreme weather condition and result in increase milk production (Lathwal, 2017).

Health care: Promote conventional vaccination program for overcome the infectious disease of animal. Infectious disease causes the decreasing in milk production and affects the health status of animal.

Conduct health care camp: Organize animal health care camp to encourage to farmers to adopt a regular preventive measure.

Privatization of health care services: Establishment of disease investigation laboratories, Dairy federation, private agencies and farmer federation for the effective treatment of animal (Lathwal, 2017).

\section{Policy and support services}

\section{Kisan credit card}

Considering the problem being faced by the farmers is having to access to credit the Government of India introduced the KISAN
CREDIT CARD scheme in the year 1998 to provide timely and adequate credit support to the farmers from banking system in a fixable, hassle free and cost.

Women SHGs: Women self help group have emerged as effective institution for providing cash credit for small enterprise and that they have very good track record on credit supply and timely recovery.

Timely supply of input such as liquid nitrogen, frozen semen, vaccine, first aid kid, feed concentrate, mineral mixture and forage seed to be paravets for onward supply to dairy animals through local dairy federation or NGOs engaged in livestock husbandry should to provide (Lathwal, 2017).

\section{Profit enhancing livestock waste management}

\section{Vermicompost}

Cow dung is valuable by product and has multifarious uses. It can be used as fuel and manure. It is also a bio oxidation and stabilization process of organic material that in contrast to compositing, involve the joint action of earthworm and micro-organism and does not involve a thermopiles stage. Finished vermicomposed should have a rich earthy smell if properly processed by worm from the waste left by a bovine of $400 \mathrm{~kg}$ body weight about 800-1000 kg vermicomposed can be produced annually.

\section{Biogas production technology}

Gas production from anaerobic biomass digestion is a famous technology biogas is a gaseous fuel generated from biological decomposition via by product. Biogas is a clean, renewable source of energy which can be used as a substitute for other nonrenewable fuel in order to save energy in rural area (Lathwal, 2017). 
Profitable manure management by livestock fish integration

Integration of fish with livestock farming is the best method for recycling of organic waste cattle manure has been used extensively. India as a source of measure in crop polyculture.

Livestock research station, NAVSARI (GUJURAT) had reported to utilize the wallowing pond made for buffaloes for freshwater agriculture with fish yield of 5 hectare without any supplementary feeding (Lathwal, 2017).

Livelihood improvement of landless and marginal farmers via small ruminant rearing

India holds world's 2nd and $3^{\text {rd }}$ rank in goat and sheep population $135.7 \%$ and $65 \%$ millions. Small ruminant referred as mobile banks and assets for economic security of farmers. Goat rearing is the backbone of economy of small and landless farmers in India goat are also known as "mini cow" or "poor man's cow" is a multipurpose animal to provide meat, hide, fur and manure for soil. it provide alternative source of livelihood.

\section{Contract farming}

Contract farming carried out an agreement between buyer and farmer. That helps to reduce the risk of production price and market. It also provides financial support and technical guideline to the farmers (Kachhiapatel, 2018).

\section{Integrated farming system}

It is one of the best options toward strengthening of small holder farm income to guarantee sustainable livelihood.

Integration of resources is made through a combination of land, water and animal resources of a farm through skillful planning including recycling of bio resources. The farm waste is better recycled for productive purposes in the IFS (Kachhiapatel, 2018).

\section{Role of government}

Extension agents and other ICT tools help to provide information to the farmers to overcome the infectious disease of animal.

State government organize camp, like- Krishi Mela in Krishi Vigan Kendra for famers to provide information regarding adoption of latest technology related with livestock.

Educating livestock farmers about various method of production of value added product,

Also help in provide loan with low interest to the farmers.

Provide insurance to famers during natural climatic condition.

Schemes (Annual Report 2017-2018)

\section{Livestock health and disease control scheme}

Centrally sponsored scheme launched buy the DADF (2010) Efforts are made towards prevention, control and treatment of animal from economic importance diseases such as; Foot and mouth disease, Hemorrhagic septicemia, Black quarter in cattle and New castle disease in poultry etc.

\section{Dairy entrepreneurship development scheme}

Objective of that scheme to generate self employment opportunity in Dairy Sector in the country this scheme being implemented through NABARD which provide financial assistance. 


\section{Feed and fodder development scheme}

Objective of that scheme to overcome the storage of feed and fodder, improve the nutritional quality of the fodder for livestock. It is mention that India with only $2.29 \%$ of the land area of the world is maintaining about $10.71 \%$ of the livestock population of the world. Through that scheme;

Introducing of fodder crops in existing crop rotation demonstration of superior use of fertilizers water and soil management introduction of cultivated fodder crops.

Demonstration of improvement and management of natural Grassland and study there proper utilization in combination within forage crops.

Demonstration of different method of water conservation.

\section{Rashtriya Gokul Mission}

Implemented by Department of Animal Husbandry Dairying and Fisheries for development and conservation of indigenous breed. That scheme is implementing for upliftment of about $80.00 \%$ low producing indigenous animals. Objective of that scheme to enhance milk production and improve genetic makeup of indigenous cattle breeds.

\section{National Mission on bovine production}

Pashu Sanjivani: Animal Wellness program.

Advanced Reproductive Technology: Used to improve availability of disease face indigenous female bovine through of sex sorted semen Technology through which only female is produced.

E-PashuHaat: The E-market Portal for bovine germplasm which provided real time data on availability of high-quality germplasm along with identification traceability of germplasm sold through e -market connecting breeder's agencies and stockholders.

National bovine genomic center: Center will play a crucial role in identification of disease free high genetic merit bull of indigenous breeds. The National Bovine Genomic center will pave for sex systematic and fare pace improvement of the previous indigenous animal resource using highly precise gene breeding Technology.

Modern technology like sexing of semen is being taken up to regulate the sex ratio and produce large number of progenies with one sex. Female sex sorted semen is made available to farmers to produce more number of high genetic merit female to increase milk production and profitability. The sex sorted semen technology will be standardized for indigenous breed's e.g. Sahiwal, Gir, Red Sindhi, Haryana.

\section{Improvement strategies}

I. With the help of conducting camp in villages through which motivate the farmers to adopt improved livestock management practices.

II. Development of local institution such as co-operative societies, SHGs which provide financial support and credit to the farmers during critical conditions.

III. Development of common fodder resources which reduce the shortage of fodder during scarcity period.

IV. Timely deworming and vaccination of animal help to decrease the chance of infection. 


\begin{tabular}{|c|c|c|c|}
\hline S.NO. & SPECIES & POPULATION & $\begin{array}{l}\text { \% SHARE IN } \\
\text { WORLD'S } \\
\text { LIVESTOCK }\end{array}$ \\
\hline 1 & Buffalo & 108.7 million & $56.7 \%\left\{1^{\mathrm{st}}\right\}$ \\
\hline 2 & Cattle & 190.9 million & $12 . \%\left\{2^{\text {nd }}\right\}$ \\
\hline 3 & Sheep & 65 million & $\left(3^{\text {rd }}\right)$ \\
\hline 4 & Goat & 135.1 million & $\begin{array}{l}2.4 \% \\
\left(2^{\text {nd })}\right.\end{array}$ \\
\hline 5 & Poultry & 729.2 million & $3.1 \%\left(5^{\text {th }}\right)$ \\
\hline 6 & Pig & 10.29 million & $1.5 \%$ \\
\hline $\begin{array}{l}\text { TOTALLIVESTCOK } \\
\text { POPULATION }\end{array}$ & ...... & 512 million & ...... \\
\hline
\end{tabular}

Role of veterinarian to double the farmer's income

Guide livestock farmers regarding animal husbandry management practices such as; feeding, house and health management, prevention of economic importance of diseases. Proving information reading timely vaccination.

Give information about livestock policy and schemes; Dairy Entrepreneurship Development Programme, National livestock mission to the landless and small farmers.

Give knowledge of value addition of milk and milk by product and also to guide them for export.

Teach farmers regarding benefit of diversification in animal husbandry sector.

Conclusion of the study is as follows:

Doubling real incomes of farmers by 2022 is a formidable task but it can be possible only through the proper implementation of the appropriate strategies.

Farming is a skilled profession and hence, people could be skilled and motivated through various skill development program of the government.

Awareness about opportunities available for commercialization and diversification, better technologies, facilities, markets, insurance, climate change, government policies, etc. must be created among the farmers.

Farmers needed to transform into entrepreneur to double the farmer's income through adopting innovation approach and technology.

\section{References}

Annual Report (2017-2018) Department of Animal Husbandry, Dairying \& Fisheries: 4-87.

Birthal S.P, Jumrani J. (2017) Reinvigorate livestock to double the farmer'sincome, The Financial Express.

Chand R. (2017) Doubling of farmer's income, Rational, Strategy, Prospect and action plan. Niti Policy Paper: 519.

Choudhary S, Yamini, Raheja N, Barman D, Prashad K, Panchbhai G (2018) Doubling of farmers income of country: Ways and means, Dairy planner: 9-11.

Dinani O.P, Tyagi. R, Giri.AandPopat. $\mathrm{D}(2018)$ Role of livestock in doubling the farmer's income national perspective and the way forward, International journal of science, environment and technology: 497-503. 
Kachhiapatel A.J(2018) Strategies to double the income of dairy farmers in India, Compendium Smallholders livestock's producers in India opportunities and challenges organized at Dantiwada, Gujarat $11^{\text {th }}-13^{\text {th }}$ April: $31-37$.

Kumar, S, Chahal V.P (2018) Doubling farmers' income: Possible way out, Indian farming: 95-96.

Kumari B (2017). Importance of livestock sector in doubling of farmer's income by 2022. Indian journal of economics and development. Pp. 136-140.

Lathwal S.S, Devi I and Dudi, K (2018) Strategies for enhancing income of smallholder livestock farmers in western India. Compendium Smallholders livestock's producers in India opportunities and challenges organized at Dantiwada, Gujarat 11-13 April: 42-52.

\section{How to cite this article:}

Deepika Tekam, Nikita Sonawane, Adhiti Bhanotra and Manish Sawant. 2019. Doubling of Farmers Income through Animal Husbandry by 2022. Int.J.Curr.Microbiol.App.Sci. 8(02): 3246-3255. doi: https://doi.org/10.20546/ijcmas.2019.802.379 